Article

\title{
Statistical Evaluation of Mechanical Properties of Slag Based Alkali-Activated Material
}

\author{
Martin Sisol, Dušan Kudelas * (), Michal Marcin, Tomáš Holub and Peter Varga \\ Institute of Earth Resources, Faculty of Mining, Ecology, Process Control and Geotechnologies Technical \\ University of Košice, Letná 9, 04001 Košice, Slovakia; martin.sisol@tuke.sk (M.S.); \\ michal.marcin@tuke.sk (M.M.); tomas.holub@tuke.sk (T.H.); tratecsro@gmail.com (P.V.) \\ * Correspondence: dusan.kudelas@tuke.sk
}

Received: 25 September 2019; Accepted: 23 October 2019; Published: 25 October 2019

\begin{abstract}
Slag is one of the by-products of the energy industry, which is suitable for secondary industrial processing. Although slag has been successfully used in industrial production for several decades, its use does not achieve the level of its potential. Today, to achieve a sustainable construction industry, alternative types of cement have been extensively investigated. Geopolymer is a kind of material which is obtained from the alkaline activator and it can be produced from the industrial wastes or by-products. In this study, $\mathrm{SiO}_{2} / \mathrm{Na}_{2} \mathrm{O}$ ratio and the amount of $\mathrm{Na}_{2} \mathrm{O}$ in activation solution parameters of alkali-activated materials were tested how they affect the strengths of hardened geopolymers from ground granulated blast furnace slag (GGBFS). Compressive and flexural strength tests were conducted, and the results were analyzed by analysis of variance (ANOVA). Strengths were tested after 7,28 , and 90 days.
\end{abstract}

Keywords: geopolymer; slag; compressive strength; flexural strength

\section{Introduction}

Portland cement is the most widely used binder in the concrete industry. Its annual worldwide production is expected to grow from approximately 2.54 billion tons in 2006 to 4.38 billion tons in 2050 based on $5 \%$ growth per year. Ordinary Portland cement (OPC)-based concrete is the most used construction. Portland cement contributes to about 5-6\% of global $\mathrm{CO}_{2}$ emission. Search for several alternatives-such as alkali-activated cement, calcium sulphoaluminate cement, etc.-are being made with the advantages of Portland cement [1,2]. In recent years, geopolymer has attracted considerable attention because of its early compressive strength, low permeability, good chemical resistance, and excellent fire resistance behavior [3,4]. Because of these advantageous properties, the geopolymer is a promising candidate as an alternative to ordinary Portland cement for developing various sustainable products in making building materials, concrete, fire-resistant coatings, fiber reinforced composites, and waste immobilization solutions for the chemical and nuclear industries. Geopolymers are emerging as a green alternative to Portland cement as they exhibit comparable mechanical properties and have significantly lower $\mathrm{CO}_{2}$ emissions. During the past two decades, significant research has sought alternatives to OPC concrete, one of which is geopolymer concrete, which can be manufactured from industrial waste materials. As such geopolymer concretes have the potential to be the next generation of highly sustainable construction material [4-6].

Geopolymers are environmentally friendly specimens that can be made from an appropriate aluminosilicate source such as fly ash. The term geopolymer was first used by Joseph Davidovits. He defined the material that is formed in inorganic polycondensation called geopolymerization $[7,8]$.

Geopolymers are synthetic alumino-silicate binders formed by the reaction between oxides and silicates of Si and Al. They are amorphous in nature and exhibit characteristic three-dimensional 
frameworks of $\mathrm{SiO}_{4}$ and $\mathrm{AlO}_{4}$ tetrahedra like that of zeolite structure [9]. The mechanism for geopolymers is a polymerization process that involves a chemical reaction of alumina-silicate materials in the presence of an alkaline medium which results in the formation of three-dimensional polymeric chain [10]. For geopolymers, activation is required for the polymerization reaction which can be attained with alkaline compounds such as $\mathrm{NaOH}$-based, $\mathrm{KOH}$-based, or a mixture of $\mathrm{Na}_{2} \mathrm{O}$ and $\mathrm{SiO}_{2}$-based. They have numerous advantages as binders because they can provide mechanical strength up to $100 \mathrm{MPa}$, better chemical resistance to sulphates and harmful acids, low creep and shrinkage, high early strength, and resistance to highly elevated temperatures [11-13].

Geopolymers can be used in many fields of industry such as transportation, metallurgy, emergency repairs, membrane materials and nuclear waste disposal. Regardless of important profitable and technological potential geopolymers character limits their widespread applications where excessive efforts are made to overcome such deficiencies. Many studies are devoted to optimizing the strength of geopolymer products and to comprehend the geopolymerization mechanism [14-17].

Bernal et al. [18] examined the development of binder structure in sodium silicate-activated slag-fly ash mixtures to determine the effects of slag addition on the final geopolymers strength. $\mathrm{SiO}_{2} / \mathrm{Al}_{2} \mathrm{O}_{3}$ ratio, $\mathrm{R}_{2} \mathrm{O} / \mathrm{Al}_{2} \mathrm{O}_{3}$ ratio, $\mathrm{SiO}_{2} / \mathrm{R}_{2} \mathrm{O}$ ratio $\left(\mathrm{R}=\mathrm{Na}^{+}\right.$or $\left.\mathrm{K}^{+}\right)$and liquid/solid ratio were the most significant factors which affected the properties of geopolymer binders. Therefor desired mechanical strength, amorphous structure of geopolymers is desirable as many research concluded. The association amongst the compressive strength and $\mathrm{SiO} 2 / \mathrm{R} 2 \mathrm{O}$ ratio showed that an rise in alkali content or reduction in silicate content increases the mechanical strength of geopolymers idicates the formation of aluminosilicate network structures [19-22].

Naturally, the optimal geopolymer strength was described with the $\mathrm{SiO}_{2} / \mathrm{Al}_{2} \mathrm{O}_{3}$ ratio in the range of 3.0-3.8 and $\mathrm{Na}_{2} \mathrm{O} / \mathrm{Al}_{2} \mathrm{O}_{3}$ ratio of $\sim 1$ [23]. Changes in $\mathrm{SiO}_{2} / \mathrm{Al}_{2} \mathrm{O}_{3}$ ratio outside this range have been found to outcome in lower strength. The setting time of geopolymer binders increased with increasing $\mathrm{SiO}_{2} / \mathrm{Al}_{2} \mathrm{O}_{3}$ ratio of the initial mixture. The same authors examined the $\mathrm{Al}_{2} \mathrm{O}_{3} / \mathrm{SiO}_{2}$ ratio dependent on hardening and setting of the geopolymer system. This ratio proved the effects of setting time and final mechanical strength of the geopolymer [23].

On the other hand, the alkali reactant ratio can also be represented in term of $\mathrm{SiO}_{2} / \mathrm{Na}_{2} \mathrm{O}$ molar ratio. Increasing $\mathrm{SiO}_{2} / \mathrm{Na}_{2} \mathrm{O}$ ratio slower down the reaction and delays the setting of paste. A system with a Na-silicate solution has a slower rate of reaction than that of K-silicate solution. Davidovits suggested the $\mathrm{SiO}_{2} / \mathrm{Na}_{2} \mathrm{O}$ ratio for alkaline reactant of 1.85 in order to achieve higher strength and durability [24].

Chindaprasirt examined the effect of $\mathrm{SiO}_{2} / \mathrm{Al}_{2} \mathrm{O}_{3}$ and $\mathrm{Na}_{2} \mathrm{O} / \mathrm{SiO}_{2}$ ratios on the setting time, workability, and the final mechanical strength of geopolymer system. It was recognized that the suitable ratios ranged between 2.87 to 4.79 for $\mathrm{SiO}_{2} / \mathrm{Al}_{2} \mathrm{O}_{3}$ and within 1.2 to 1.4 for $\mathrm{SiO}_{2} / \mathrm{Na}_{2} \mathrm{O}$ for geopolymer binder [25]. Bernal and Provis addressed used the accelerated degradation testing methods to determine the effects of increased concentrations of $\mathrm{CO}_{2}$, sulfates, and chlorides on the durability [26].

Davidovits recommended the composition of geopolymers should fall in order to obtain high-strength, durable products. Even so, he concluded the ideal $\mathrm{Na}_{2} \mathrm{O} / \mathrm{Al}_{2} \mathrm{O}_{3}$ and $\mathrm{SiO}_{2} / \mathrm{Al}_{2} \mathrm{O}_{3}$ ratios are about 1.00 and 4.00 , respectively [25].

In this paper, we conducted several experiments based on our previous research with GGBFS.

\section{Materials and Methods}

The material used for alkali activation was ground granulated blast furnace slag (GGBFS) from which geopolymer samples were created. Chemical analysis of material is in Table 1. Because of slag lumps, it was necessary to grind material. Material was grinded in laboratory ball mill using steel balls with different diameter. After grinding stage d 80 was $120 \mu \mathrm{m}(80 \%$ of material was passing $120 \mu \mathrm{m}$ sieve). The material was homogenized before alkali activation. No other treatment was applied to the material. SEM pictures of materials are in Figure 1. 
Table 1. Chemical composition of material.

\begin{tabular}{cccccccc}
\hline Material & $\mathrm{SiO}_{2}$ & $\mathrm{CaO}$ & $\mathrm{MgO}$ & $\mathrm{Al}_{2} \mathrm{O}_{3}$ & $\mathrm{Fe}_{2} \mathrm{O}_{3}$ & Other \\
\hline GGBFS (\%) & 40.3 & 37.01 & 12.1 & 8.51 & 0.3 & 1.78 \\
\hline & & & & & & & \\
\hline
\end{tabular}

Figure 1. SEM pictures of GGBFS.

The activation solution was prepared by mixing solid $\mathrm{NaOH}$ pellets with $\mathrm{Na}$-water glass and water. Sodium water glass from the Kittfort Praha Co. with the density of $1.328-1.378 \mathrm{~g} / \mathrm{cm}^{3}$ was used. It contains $36-38 \% \mathrm{Na}_{2} \mathrm{SiO}_{3}$ and the molar ratio of $\mathrm{SiO}_{2} / \mathrm{Na}_{2} \mathrm{O}$ is 3.2-3.5. Solid $\mathrm{NaOH}$ with the density of $2.13 \mathrm{~g} / \mathrm{cm}^{3}$ was obtained from Kittfort Praha Co. containing at least $97-99.5 \%$ of $\mathrm{NaOH}$.

The effect of two main parameters was examined, amount of $\mathrm{Na}_{2} \mathrm{O}$ (\%) from slag weight (ratio of $\mathrm{Na}_{2} \mathrm{O}$ in activation solution and amount of GGBFS) and $\mathrm{SiO}_{2} / \mathrm{Na}_{2} \mathrm{O}$ ratio $(\mathrm{mol} / \mathrm{mol})$ in activation solution on strengths of geopolymers. A selection of 28 different mixtures were designed in which the amount of $\mathrm{Na}_{2} \mathrm{O}$ varied from 5 to 8 and with a varying $\mathrm{SiO}_{2} / \mathrm{Na}_{2} \mathrm{O}$ ratio from 0 to 1.4. The water-to-fly ash ratio (w) was adjusted to 0.25 . GGBFS mixture was stirred with activation solution for 10 minutes until the creation of homogenous mixture. The mixture was then filled into prismatic molds with the dimensions $40 \times 40 \times 160 \mathrm{~mm}$ and compacted on the vibration table VSB-40. The pastes were cured in a hot air-drying chamber at $80{ }^{\circ} \mathrm{C}$ for 6 hours. Higher temperature in first hours was chosen to accelerate geopolymerization process and reduce cracking due to shrinkage. Thereafter, the samples were removed from the forms, marked, and stored in laboratory conditions until the moment of the strength test. The values of mechanical strength were determined according to the Slovak Standard STN EN 12390-3, which means after 7, 28, and 90 days were performed compressive and flexural strengths. The three same samples were broken into halves to determine flexural strength and six halves were tested for compressive strengths. The mechanical strengths of the hardened samples was determined using the hydraulic machine Form + Test MEGA 100-200-10D. Whole experiments designs with results are shown in Table 2. 
Table 2. Experiment design with results.

\begin{tabular}{|c|c|c|c|c|c|c|c|c|c|}
\hline Sample & $\mathrm{Na}_{2} \mathrm{O}$ & $\mathrm{SiO}_{2} / \mathrm{Na}_{2} \mathrm{O}$ & $\mathbf{W}$ & Flex. & Compress. & Flex. & Compress. & Flex. & Compress. \\
\hline & $\%$ & $\mathrm{~mol} / \mathrm{mol}$ & & \multicolumn{2}{|c|}{7 days } & \multicolumn{2}{|c|}{28 davs } & \multicolumn{2}{|c|}{90 days } \\
\hline 1 & 5 & 0 & 0.25 & 3.3 & 9.4 & 4.6 & 11.4 & 3.3 & 16.6 \\
\hline 2 & 6 & 0 & 0.25 & 4.7 & 9.2 & 4.6 & 10.9 & 4.1 & 16.2 \\
\hline 3 & 7 & 0 & 0.25 & 5.2 & 8.5 & 4.6 & 10 & 5.3 & 15.3 \\
\hline 4 & 8 & 0 & 0.25 & 4.5 & 8.4 & 5.9 & 11.1 & 5.2 & 17.9 \\
\hline 5 & 5 & 0.25 & 0.25 & 2.8 & 11.8 & 3 & 13.3 & 2.5 & 22.9 \\
\hline 6 & 6 & 0.25 & 0.25 & 2.7 & 7.6 & 3.4 & 9.3 & 3.4 & 16.7 \\
\hline 7 & 7 & 0.25 & 0.25 & 2.8 & 6.6 & 4.2 & 6.7 & 4 & 12.7 \\
\hline 8 & 8 & 0.25 & 0.25 & 4 & 7.7 & 4.9 & 7.9 & 3.8 & 12.7 \\
\hline 9 & 5 & 0.5 & 0.25 & 3.3 & 18.5 & 3.3 & 22.1 & 4 & 29.8 \\
\hline 10 & 6 & 0.5 & 0.25 & 3.5 & 17.3 & 4.1 & 19.5 & 4.6 & 28.1 \\
\hline 11 & 7 & 0.5 & 0.25 & 5.5 & 20.8 & 6.3 & 24.4 & 3.6 & 30.9 \\
\hline 12 & 8 & 0.5 & 0.25 & 4.7 & 15.7 & 6.6 & 15.8 & 4.9 & 24 \\
\hline 13 & 5 & 0.75 & 0.25 & 4.9 & 32.6 & 5.3 & 38 & 4.5 & 33.3 \\
\hline 14 & 6 & 0.75 & 0.25 & 4.8 & 25.7 & 4 & 32.9 & 4.9 & 32.9 \\
\hline 15 & 7 & 0.75 & 0.25 & 3.3 & 14.9 & 3.4 & 21.5 & 3.5 & 18.4 \\
\hline 16 & 8 & 0.75 & 0.25 & 2.3 & 9.7 & 2.2 & 15.1 & 1.9 & 15.3 \\
\hline 17 & 5 & 1 & 0.25 & 4.2 & 37.6 & 4.3 & 40.2 & 2.5 & 34.3 \\
\hline 18 & 6 & 1 & 0.25 & 3.3 & 32.9 & 5.6 & 36.6 & 4 & 37.8 \\
\hline 19 & 7 & 1 & 0.25 & 3.5 & 31.6 & 2.1 & 37.2 & 2.8 & 34.9 \\
\hline 20 & 8 & 1 & 0.25 & 4.6 & 28.6 & 2.6 & 33.2 & 3.2 & 31.4 \\
\hline 21 & 5 & 1.2 & 0.25 & 5.2 & 44.2 & 6.2 & 44.7 & 5 & 45 \\
\hline 22 & 6 & 1.2 & 0.25 & 5.4 & 42.7 & 5 & 44.6 & 3.9 & 44.2 \\
\hline 23 & 7 & 1.2 & 0.25 & 4.3 & 39.3 & 5 & 41.6 & 5.2 & 39.7 \\
\hline 24 & 8 & 1.2 & 0.25 & 5.7 & 21.5 & 5.4 & 23.5 & 5.7 & 23 \\
\hline 25 & 5 & 1.4 & 0.25 & 4.1 & 49.4 & 3.6 & 51.2 & 3.2 & 48.7 \\
\hline 26 & 6 & 1.4 & 0.25 & 4.5 & 52.5 & 3.5 & 52.7 & 4 & 52.2 \\
\hline 27 & 7 & 1.4 & 0.25 & 3.9 & 47.5 & 4 & 51.9 & 3.9 & 50.5 \\
\hline 28 & 8 & 1.4 & 0.25 & 2.2 & 39 & 2.7 & 43.3 & 1.5 & 40.1 \\
\hline
\end{tabular}

\section{Results}

In this study, two parameters of alkali activated materials were tested how they affect the strengths of hardened geopolymers. From the design of experiments, 28 samples were tested after 7, 28, and 90 days, made them 84 tested samples. Compressive and flexural strengths tests were made and ANOVA was obtained and evaluated. Analysis of variance (ANOVA) is a collection of statistical models and their associated estimation procedures used to analyze the differences among group means in a samples. These results are presented in this section. The basic statistical parameters can be seen in the following Table 3.

Based on the conducted experiments, the effect of main parameters of geopolymerization, $\mathrm{SiO}_{2} / \mathrm{Na}_{2} \mathrm{O}$ ratio, and amount of $\mathrm{Na}_{2} \mathrm{O}$ in activation solution on compressive and flexural strengths of geopolymers was examined. Showing the results by box plots (Figure 2a, and Figure 2b) of compressive and flexural strength, it can be seen that by increasing the hardening time, the compressive strength increases, and flexural strength reached a maximum at 28 days and at 90 days minimum. Changes in strength and pressure are statistically not significant.

From the results of the correlation analysis, it is clear that a high positive correlation is between the results of the compressive strength and the $\mathrm{SiO}_{2} / \mathrm{Na}_{2} \mathrm{O}$ ratio (Figure 3). As the $\mathrm{SiO}_{2} / \mathrm{Na}_{2} \mathrm{O}$ ratio increases, the compressive strength values also increase. This result is valid for each 7, 28, and 90 days hardening time as can be seen from the following table. Coefficients of the correlation between compressive strength and $\mathrm{Na}_{2} \mathrm{O}$ show a low negative correlation and the results are not statistically significant, see Table 4 . 
Table 3. Statistical parameters of samples.

\begin{tabular}{cccccccc}
\hline 7 Days & Valid N & Mean & Median & Min. & Max. & Variance & Std. Dev \\
\hline $\mathrm{Na}_{2} \mathrm{O}(\%)$ & 28.00 & 6.50 & 6.50 & 5.00 & 8.00 & 1.30 & 1.14 \\
$\mathrm{SiO}_{2} / \mathrm{Na}_{2} \mathrm{O}(-)$ & 28.00 & 0.73 & 0.75 & 0.00 & 1.40 & 0.23 & 0.48 \\
Flexural strength $(\mathrm{MPa})$ & 28.00 & 4.04 & 4.15 & 2.20 & 5.70 & 0.98 & 0.99 \\
Compress. strength $(\mathrm{MPa})$ & 28.00 & 24.69 & 21.15 & 6.60 & 52.50 & 221.60 & 14.89 \\
\hline $\mathbf{2 8}$ Days & Valid N & Mean & Median & Min. & Max. & Variance & Std. Dev \\
\hline $\mathrm{Na}_{2} \mathrm{O}(\%)$ & 28.00 & 6.50 & 6.50 & 5.00 & 8.00 & 1.30 & 1.14 \\
$\mathrm{SiO}_{2} / \mathrm{Na}_{2} \mathrm{O}(-)$ & 28.00 & 0.73 & 0.75 & 0.00 & 1.40 & 0.23 & 0.48 \\
Flexural strength $(\mathrm{MPa})$ & 28.00 & 4.30 & 4.25 & 2.10 & 6.60 & 1.53 & 1.24 \\
Compress. strength $(\mathrm{MPa})$ & 28.00 & 27.52 & 23.95 & 6.70 & 52.70 & 231.26 & 15.21 \\
\hline $\mathbf{9 0 ~ D a y s ~}$ & Valid N & Mean & Median & Min. & Max. & Variance & Std. Dev \\
\hline $\mathrm{Na}_{2} \mathrm{O}(\%)$ & 28.00 & 6.50 & 6.50 & 5.00 & 8.00 & 1.30 & 1.14 \\
$\mathrm{SiO}_{2} / \mathrm{Na}_{2} \mathrm{O}(-)$ & 28.00 & 0.73 & 0.75 & 0.00 & 1.40 & 0.23 & 0.48 \\
Flexural strength $(\mathrm{MPa})$ & 28.00 & 3.87 & 3.95 & 1.50 & 5.70 & 1.09 & 1.04 \\
Compress. strength $(\mathrm{MPa})$ & 28.00 & 29.48 & 30.35 & 12.70 & 52.70 & 148.19 & 12.17 \\
\hline
\end{tabular}

Notes: (-) means ratio (mol/mol), dimensionless number.

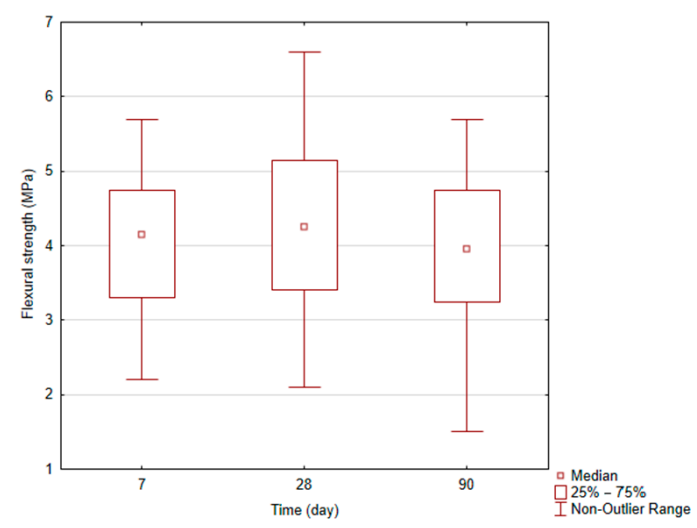

(a)

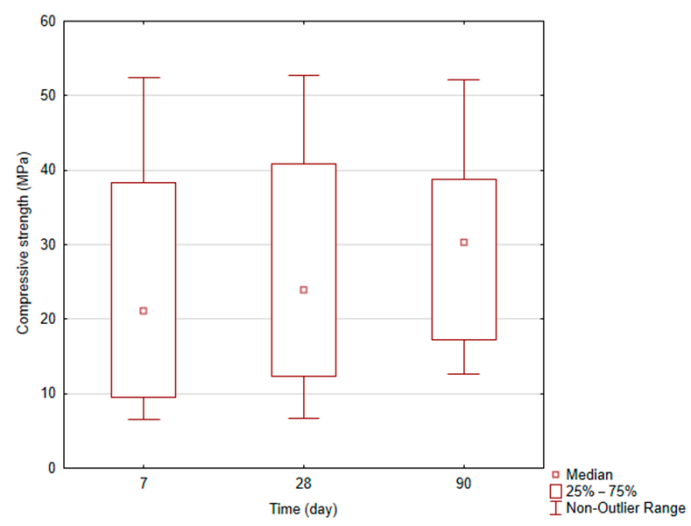

(b)

Figure 2. (a). Box plots-flexural strength. (b). Box plots-compressive strength.
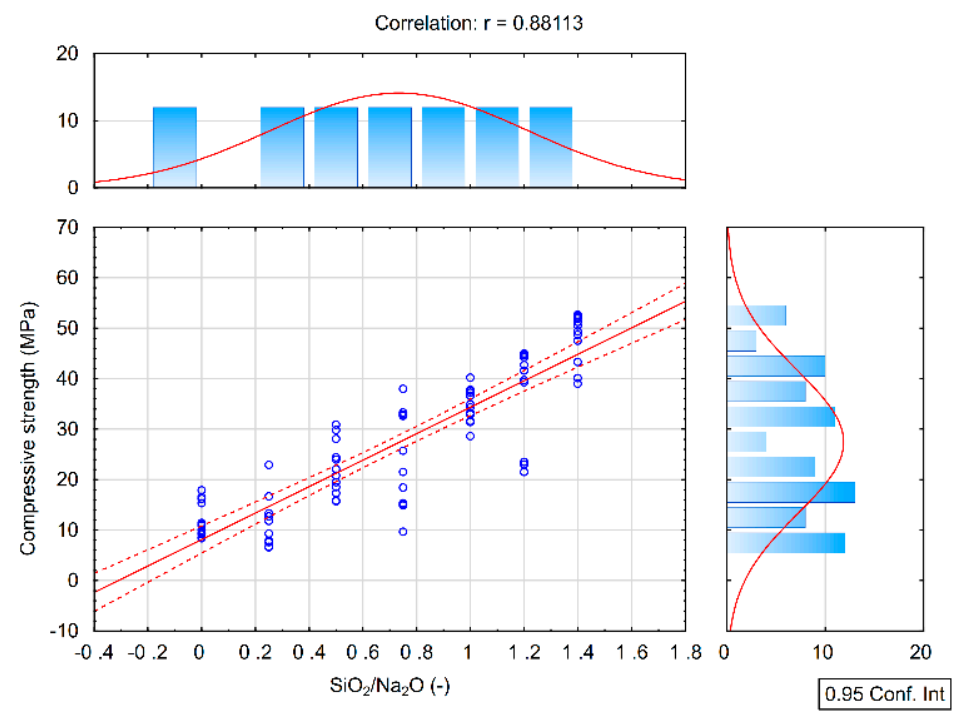

Figure 3. Correlation analysis of the compressive strength and the $\mathrm{SiO}_{2} / \mathrm{Na}_{2} \mathrm{O}$ ratio. 
Table 4. Correlations analysis.

\begin{tabular}{ccc}
\hline 7 Days & Flexural Strenght (MPa) & Compressive Strength (MPa) \\
\hline $\mathrm{Na}_{2} \mathrm{O}(\%)$ & 0.003282 & -0.259389 \\
$\mathrm{SiO}_{2} / \mathrm{Na}_{2} \mathrm{O}(-)$ & 0.114724 & 0.905184 \\
\hline $\mathbf{2 8} \mathrm{Days}$ & Flexural Strenght (MPa) & Compressive Strength (MPa) \\
\hline $\mathrm{Na}_{2} \mathrm{O}(\%)$ & -0.007887 & -0.241935 \\
$\mathrm{SiO}_{2} / \mathrm{Na}_{2} \mathrm{O}(-)$ & -0.166900 & 0.915196 \\
\hline $\mathbf{9 0 ~ D a y s}$ & Flexural Strenght (MPa) & Compressive Strength (MPa) \\
\hline $\mathrm{Na}_{2} \mathrm{O}(\%)$ & 0.046731 & -0.299692 \\
$\mathrm{SiO}_{2} / \mathrm{Na}_{2} \mathrm{O}(-)$ & -0.147759 & 0.854066 \\
\hline
\end{tabular}

Notes: (-) means ratio (mol/mol), dimensionless number.

We created 3D surface charts to observe the compression strength and flexural strength of samples. Approximation of results was performed using the least squares of weighted distances. From the results obtained, it can be observed that the dependency patterns during the different hardening times are comparable and maximum compressive strengths are reached at the maximum values of $\mathrm{SiO}_{2} / \mathrm{Na}_{2} \mathrm{O}$ ratio 1.4 and $\mathrm{Na}_{2} \mathrm{O} 6 \%$. Minimum compressive strengths are achieved at the $6 \%$ of $\mathrm{Na}_{2} \mathrm{O}$ and 0 value of $\mathrm{SiO}_{2} / \mathrm{Na}_{2} \mathrm{O}$ ratio. Figure 4 describes the effect of observed factors on compressive strengths of geopolymers. As the $\mathrm{SiO}_{2} / \mathrm{Na}_{2} \mathrm{O}$ ratio increases from 0 , strengths increase to their maximum. After 7 days of hardening samples, best results in case of flexural strength were $8 \%$ of $\mathrm{Na}_{2} \mathrm{O}$ and $1.2 \mathrm{SiO}_{2} / \mathrm{Na}_{2} \mathrm{O}$ ratio. Compressive strength has best results in a sample with $5 \%$ of $\mathrm{Na}_{2} \mathrm{O}$ and 1.4 $\mathrm{SiO}_{2} / \mathrm{Na}_{2} \mathrm{O}$ ratio. Twenty-eight days after alkali activation of samples results shown similar strengths, best was again $8 \%$ of $\mathrm{Na}_{2} \mathrm{O}$ but only $0.5 \mathrm{SiO}_{2} / \mathrm{Na}_{2} \mathrm{O}$ ratio, in case of compressive strengths it was $6 \%$ of $\mathrm{Na}_{2} \mathrm{O}$ and $1.4 \mathrm{SiO}_{2} / \mathrm{Na}_{2} \mathrm{O}$ ratio. Last samples hardened 90 days shows that in case of flexural strengths it is hard to make any prediction were should be best strengths, see Figure 5. Flexural strength of sample with $8 \%$ of $\mathrm{Na}_{2} \mathrm{O}$ and $1.2 \mathrm{SiO}_{2} / \mathrm{Na}_{2} \mathrm{O}$ ratio has the biggest strength. Compressive strength in our samples was as we predicted because it is very similar to another result, the best sample was with $6 \%$ of $\mathrm{Na}_{2} \mathrm{O}$ and $1.4 \mathrm{SiO}_{2} / \mathrm{Na}_{2} \mathrm{O}$ ratio same as at 28 days. Further increases of the $\mathrm{SiO}_{2} / \mathrm{Na}_{2} \mathrm{O}$ ratio should lead to more increased compressive strengths.

Methods of regression analysis and analysis of variance (ANOVA), a regression model was obtained and evaluated, which expresses the influence of compressive strength and flexural strength from the $\mathrm{SiO}_{2} / \mathrm{Na}_{2} \mathrm{O}$ ratio, amount of $\mathrm{Na}_{2} \mathrm{O}$ and hardening time. The ANOVA result states that the regression model is appropriate and that all input parameters are statistically significant and affect the compressive strength results. The selected regression model explains the variability of parameters to the compressive strength of approximately $86 \%$, see Table 5 . R shows a high linear correlation among $\mathrm{SiO}_{2} / \mathrm{Na}_{2} \mathrm{O}$ ratio, $\mathrm{Na}_{2} \mathrm{O}$ and compressive strength. $\mathrm{R}^{2}$ shows how well terms (data points) fit a model (3D surface chart). The adjusted $\mathrm{R}^{2}$ tells the percentage of variation explained by only the independent variables that actually affect the dependent variable. An extra $14 \%$ represents unexplained variability, the impact of random factors, and other unspecified impacts. Regression model is significant at the level of alpha 0.05 ( $p$-value). The $p$-value is less than 0.05 .

Table 5. ANOVA results.

\begin{tabular}{cccccc}
\hline Effect & Sums of Square & df & Mean Squares & F & $p$-value \\
\hline Regress. & 14259.00 & 3 & 4753.00 & 165.69737 & 0.0000000 \\
Residual & 2294.84 & 80 & 28.685 & & \\
Total & 16553.84 & & & & \\
\hline
\end{tabular}

Notes: Regression Summary for Variable: Compressive Strength (ANOVA) $R=0.928100 R^{2}=0.86137$ Adjusted $\mathrm{R}^{2}=0.856117$. 


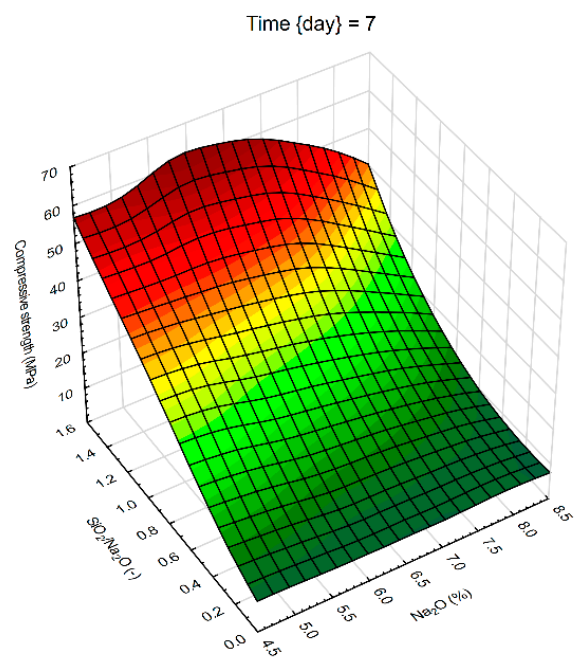

(a)

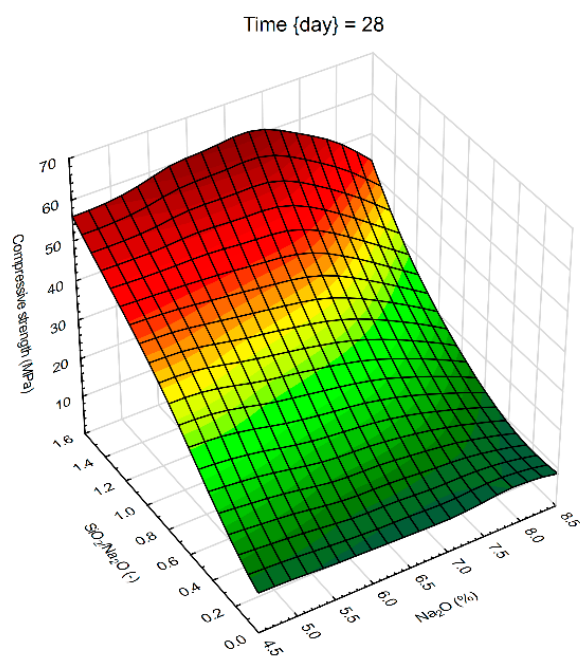

(b)

(c)

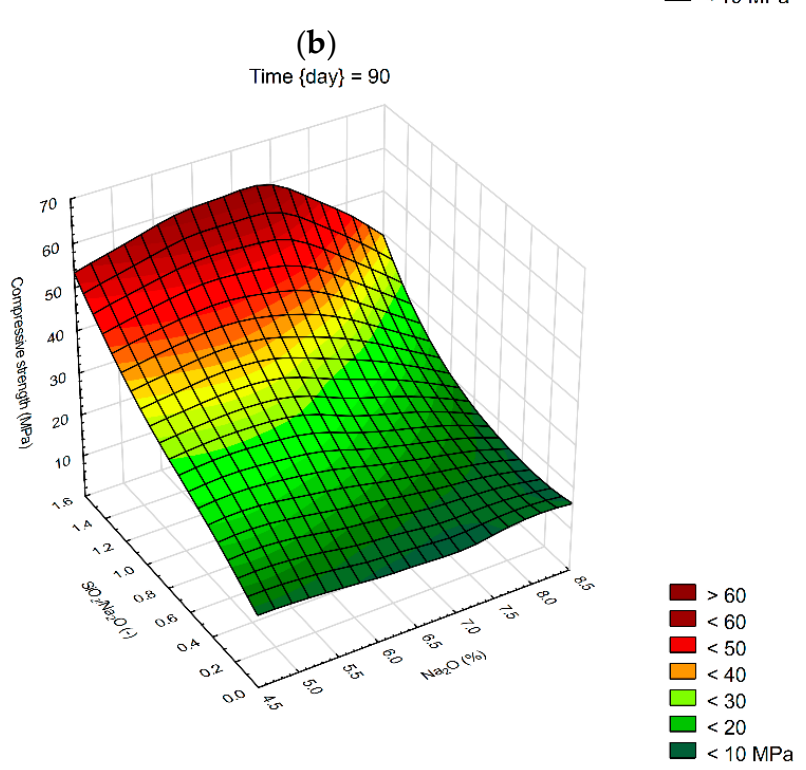

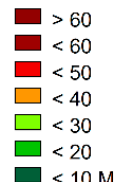

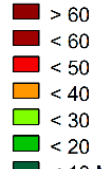

\begin{tabular}{l}
$\square<60$ \\
$\square<50$ \\
$\square<40$ \\
$\square<20$ \\
\hline$<20$
\end{tabular}

$\square<10 \mathrm{MPa}$

Figure 4. Surface charts of compressive strengths-(a) 7 days; (b) 28 days; (c) 90 days. 


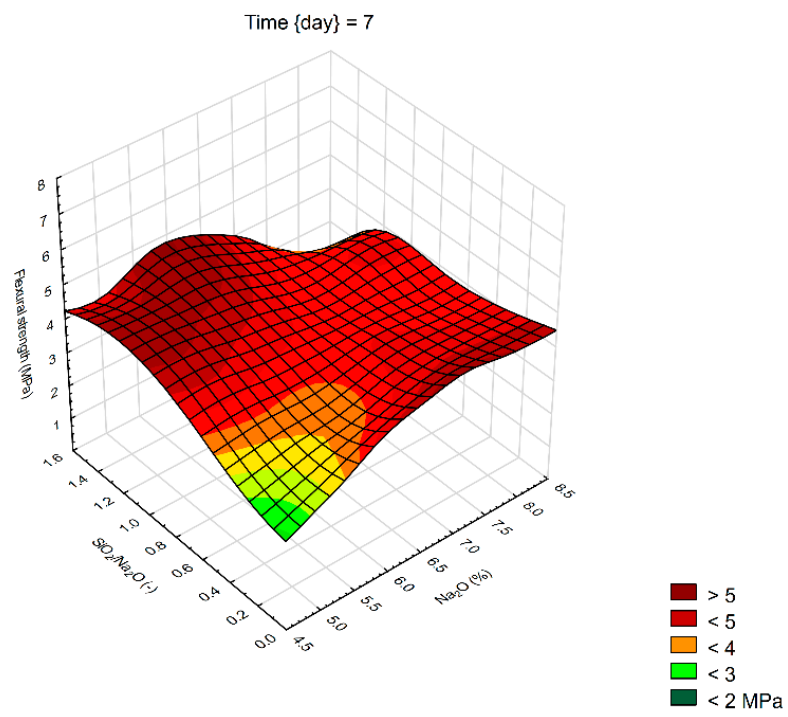

(a)

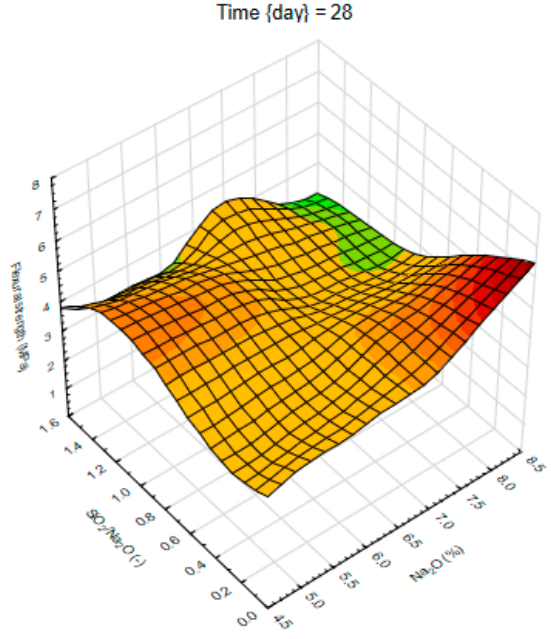

$\square>5$
$\square<5$
$\square<4$
$\square<3$
$\square<2 \mathrm{MP}$

(b)

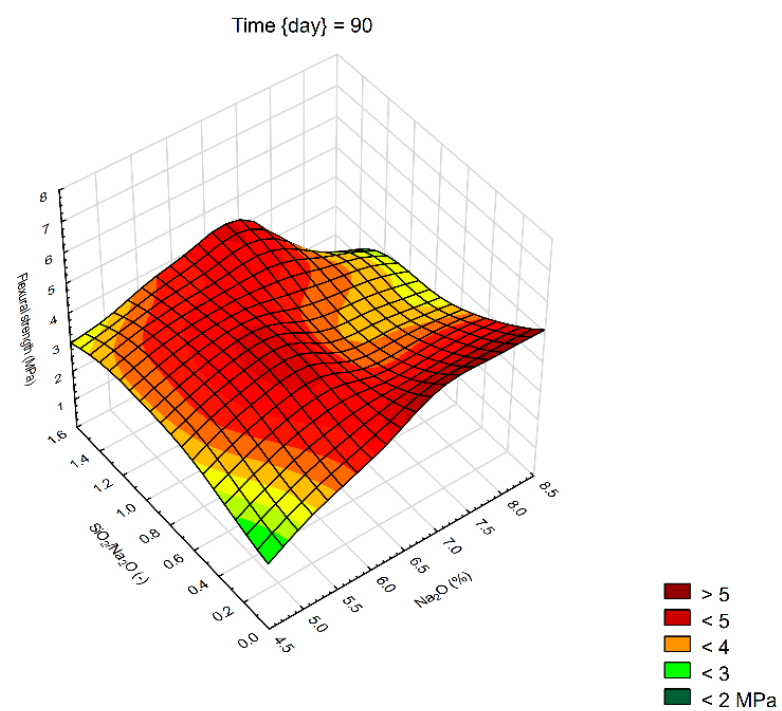

(c)

Figure 5. Surface charts of flexural strengths-(a) 7 days; (b) 28 days; (c) 90 days. 
It is not possible to create a regression model with statistical significance and reliability from flexural strength data.

\section{Discussion}

Musaddiq et al. (2017) conducted tests with GGBS with the addition of fly ash and achieved similar strengths, but with more amount of FA, strengths were lowering down. Moreover, authors cured the specimens at ambient temperature in contrary to our experiments. However, in case of FA-based geopolymers, the elevated temperature is essential for $\mathrm{SiO}_{2}$ and $\mathrm{Al}_{2} \mathrm{O}$ to form the geopolymerization products. Peyronnard et al. (2012) carried out a test with GGBS with addition others pozzolanic by-products such as waste glass (WG), copper slag (SC), and coal fly ash (CFS). Since their high reactivity, GGBFS allows the development of high mechanical strength. Their amount of binders could be adjusted to influence the strength. Authors also conducted the mechanical strengths test, but their maximum strengths were around 2.5 MPa with GGBS and even lower with addition another by-products. This can be due to their preparation method and curing temperature. Ye et al. (2017) performed tests using slag and calcined tailings mixture without any addition of water. Their samples reached in a period of 6 years compressive strengths over $75 \mathrm{MPa}$. The increase in strength with extended curing times proves the stability of the mechanical properties of the studied geopolymers. This increases the confidence in its durability. Geopolymers were stored in humidity chambers with relative humidity ranging from $40 \%$ to $80 \%$. This continuous hydration helped created denser microstructure of geopolymers.

In future experiments, we would like to continue with our materials and work with different curing regimes at ambient temperature and enhanced temperature. We proved that pure GGBFS, with no addition of fly ash or any others suitable geopolymerization materials, is enough to create satisfactory geopolymers with high mechanical strengths [27-29].

\section{Conclusions}

For many purposes, there is an increasing demand for new materials that have low $\mathrm{CO}_{2}$ emissions connected with their production. Alkali activated materials-geopolymers-are a new generation of inorganic binders. Any aluminosilicate materials can be used to prepare geopolymers, including fly ash and slag. Therefore, geopolymer concrete could possibly be utilized potentially as a replacement for OPC, however, this will only occur when both an efficient supply chain for raw materials and a supply network for the products are in place. In the present study, compressive and flexural strengths of GGBFS based geopolymers were investigated after 7, 28, and 90 days. From the results obtained, it can be observed that the dependency patterns during the different hardening times are comparable and maximum compressive strengths are reached at the maximum values of $\mathrm{SiO}_{2} / \mathrm{Na}_{2} \mathrm{O}$ ratio 1.4 and $\mathrm{Na}_{2} \mathrm{O} 6 \%$. Compressive strengths were found to increase with increases in the $\mathrm{SiO}_{2} / \mathrm{Na}_{2} \mathrm{O}$ ratio after all testing days. The ANOVA result states that the regression model is appropriate and that all input parameters are statistically significant and affect the compressive strength results.

Author Contributions: M.M., P.V., and T.H. carried out experiment. M.M., D.K., and M.S. wrote the manuscript. M.S. and D.K. supervise the experiment and conceived the original idea. D.K. processed the data. All authors discussed the results and contributed to the final manuscript.

Funding: This research was funded by the Scientific Grant Agency of the Ministry of Education, Science, Research and Sport of the Slovak Republic and the Slovak Academy of Sciences - VEGA, grant number 1/0843/15 and VEGA grant number 1/0509/18. The part of this contribution (SEM pictures) is the result of the project implementation "Research Excellence Centre on Earth Sources, Extraction and Treatment" ITMS: 26220120038, supported by the Research \& Development Operational Program funded by the ERDF.

Conflicts of Interest: We declare no conflict of interest. 


\section{References}

1. Albitar, M.; Ali, M.S.M.; Visintin, P. Experimental study on fly ash and lead smelter slag-based geopolymer concrete columns. Constr. Build. Mater. 2017, 141, 104-112. [CrossRef]

2. Parrón-Rubio, M.E.; Pérez, F.; Gonzalez-Herrera, A.; Oliveira, M.; Dolores, R. Slag Substitution as a Cementing Material in Concrete: Mechanical, Physical and Environmental Properties. Materials 2019, 12, 2845. [CrossRef] [PubMed]

3. Nath, S.K.; Kumar, S. Influence of iron making slags on strength and microstructure of fly ash geopolymer. Constr. Build. Mater. 2013, 38, 924-930. [CrossRef]

4. Gunasekara, C.; Law, D.W.; Setunge, S.; Sanjayan, J.G. Zeta potential, gel formation and compressive strength of low calcium fly ash geopolymers. Constr. Build. Mater. 2015, 95, 592-599. [CrossRef]

5. Nazari, A.; Sanjayan, J.G. Hybrid effects of alumina and silica nanoparticles on water absorption of geopolymers: Application of Taguchi approach. Measurement 2015, 60, 240-246. [CrossRef]

6. Bergamonti, L.; Taurino, R.; Cattani, L.; Ferretti, D.; Bondioli, F. Lightweight hybrid organic-inorganic geopolymers obtained using polyurethane waste. Constr. Build. Mater. 2018, 185, 285-292. [CrossRef]

7. Davidovits, J. Geopolymers: Inorganic Polymeric new materials. J. Therm. Anal. 1991, 37, $1633-1656$. [CrossRef]

8. Skvara, F. Alkali activated materials or geopolymers. Ceram. Silikáty 2007, 51, 173-177.

9. Kumar, S.; Mucsi, G.; Kristály, F.; Pekker, P. Mechanical activation of fly ash and its influence on micro and nano-structural behaviour of resulting geopolymers. Adv. Powder Technol. 2017, 28, 805-813. [CrossRef]

10. Mehta, A.; Siddique, R. An overview of geopolymers derived from industrial by-products. Constr. Build. Mater. 2016, 127, 183-198. [CrossRef]

11. Provis, J.L.; Duxson, P.; Van Deventer, J.S.J. The role of particle technology in developing sustainable construction materials. Adv. Powder Technol. 2010, 21, 2-7. [CrossRef]

12. Bakharev, T. Durability of geopolymer materials in sodium and magnesium sulfate solutions. Cem. Concr. Res. 2005, 35, 1233-1246. [CrossRef]

13. Kong, D.L.Y.; Sanjayan, J.G. Damage behavior of geopolymer composites exposed to elevated temperatures. Cem. Concr. Compos. 2008, 30, 986-991. [CrossRef]

14. Van Deventer, J.S.J.; Provis, J.L.; Duxson, P.; Lukey, G.C. Reaction mechanisms in the geopolymeric conversion of inorganic waste to useful products. J. Hazard. Mater. 2007, 139, 506-513. [CrossRef] [PubMed]

15. Zhang, H.Y.; Kodur, V.; Qi, S.L.; Wu, B. Characterizing the bond strength of geopolymers at ambient and elevated temperatures. Cem. Concr. Compos. 2015, 58, 40-49. [CrossRef]

16. He, J.; Jie, Y.; Zhang, J.; Yu, Y.; Zhang, G. Synthesis and characterization of red mud and rice husk ash-based geopolymer composites. Cem. Concr. Compos. 2013, 37, 108-118. [CrossRef]

17. Zhang, J.; He, Y.; Wang, Y.; Mao, J.; Cui, X. Synthesis of a self-supporting faujasite zeolite membrane using geopolymer gel for separation of alcohol/water mixture. Mater. Lett. 2014, 116, 167-170. [CrossRef]

18. Bernal, S.A.; Provis, J.L.; Rose, V.; de Gutierrez, R.M. Evolution of binder structure in sodium silicate-activated slag-metakaolin blends. Cem. Concr. Compos. 2011, 33, 46-54. [CrossRef]

19. Van Jaarsveld, J.G.S.; Van Deventer, J.S.J. The effect of metal contaminants on the formation and properties of waste-based geopolymers. Cem. Concr. Res. 1999, 29, 1189-1200. [CrossRef]

20. Xu, H.; Van Deventer, J.S.J. The geopolymerisation of alumino-silicate minerals. Int. J. Miner. Process. 2000, 59, 247-266. [CrossRef]

21. Zhang, B.; MacKenzie, K.J.D.; Brown, I.W.M. Crystalline phase formation in metakaolinite geopolymers activated with $\mathrm{NaOH}$ and sodium silicate. J. Mater. Sci. 2009, 44, 4668-4676. [CrossRef]

22. De Vargas, A.S.; DalMolin, D.C.C.; Vilela, A.C.V.; da Silva, F.J.; Pavão, B.; Veit, H. The effects of $\mathrm{Na}_{2} \mathrm{O} / \mathrm{SiO}_{2}$ molar ratio, curing temperature and age on compressive strength, morphology and microstructure of alkali-activated fly ash-based geopolymers. Cem. Concr. Compos. 2011, 33, 653-660. [CrossRef]

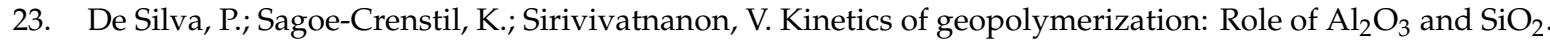
Cem. Concr. Res. 2007, 37, 512-518. [CrossRef]

24. Davidovits, J.; Buzzi, L.; Rocher, P.; Marini, D.G.C.; Tocco, S. Geopolymeric cement based on low cost geologic materials-geocistem. In Proceedings of the 2nd International Conference on Geopolymer, Saint-Quentin, France, 30 June-2 July 1999. 
25. Chindaprasirt, P.; Silva, P.D.; Crentsil, K.S.; Hanjitsuwan, S. Effect of $\mathrm{SiO}_{2}$ and $\mathrm{Al}_{2} \mathrm{O}_{3}$ on the setting and hardening of high calcium fly ash-based geopolymer systems. J. Mater. Sci. 2012, 47, 4876-4883. [CrossRef]

26. Bernal, S.A.; Provis, J.L. Durability of alkali-activated materials: Progress and perspectives. J. Am. Ceram. Soc. 2014, 97, 997-1008. [CrossRef]

27. Laskar, S.M.; Talukdar, S. Preparation and tests for workability, compressive and bond strength of ultra-fine slag based geopolymer as concrete repairing agent. Constr. Build. Mater. 2017, 154, 176-190. [CrossRef]

28. Peyronnard, O.; Benzaazoua, M. Alternative by-product based binders for cemented mine backfill: Recipes optimisation using Taguchi method. Miner. Eng. 2012, 29, 28-38. [CrossRef]

29. Ye, J.; Zhang, W.; Shi, D. Properties of an aged geopolymer synthesized from calcined ore-dressing tailing of bauxite and slag. Cem. Concr. Res. 2017, 100, 23-31. [CrossRef]

(C) 2019 by the authors. Licensee MDPI, Basel, Switzerland. This article is an open access article distributed under the terms and conditions of the Creative Commons Attribution (CC BY) license (http://creativecommons.org/licenses/by/4.0/). 